\title{
Nicotine inhibits cytokine synthesis by mouse colonic mucosa
}

\author{
Jeanette P.M. Van Dijk, G. Stanley Madretsma, Zosca J. Keuskamp, Freek J. Zijlstra * \\ Department of Pharmacology, Erasmus Unicersity Rotterdam. Rotterdam, Netherlands
}

Received 3 April 1995; accepted 4 April 1995

\begin{abstract}
We examined the in vivo effect of nicotine on the synthesis of (pro-)inflammatory mediators by mouse colonic mucosa. The synthesis of lipid mediators such as the prostanoids prostaglandin $E_{2}$, 6-keto-prostaglandin $F_{1 \text { c }}$ and thromboxane $B_{2}$, the 5-lipoxygenase products leukotriene $B_{4}$ and leukotriene $C_{4}$ and the platelet activating factor was not affected, whereas the synthesis of the pro-inflammatory cytokines interleukin- $1 \beta$ and tumor necrosis factor $\alpha$ was completely abolished. The beneficial effects of smoking and nicotine in ulcerative colitis could be attributed to this inhibition.
\end{abstract}

Keywords: Nicotinc; Colonic mucosa; Cytokine

During the last decade it has become clear that cigarette smoking not only increases the risk of developing cancer or cardiovascular disease, but surprisingly, also has beneficial effects on acne (Mills et al., 1993) and chronic diseases such as Alzheimer disease (Jones et al., 1987) and ulcerative colitis (Rhodes and Thomas, 1994). The mechanisms underlying the beneficial effects are unknown. Nicotine is the most important pharmacologically active substance in tobacco smoke and it therefore seems logical to assume it to be responsible for most of the immunoregulatory effects of cigarette smoke. Treatment of patients with active ulcerative colitis with nicotine patches proved to have a beneficial effect. Symptoms significantly improved in these patients (Pullan et al., 1994). The effects of nicotine on lipid mediators such as prostaglandins are still controversial. In rabbits prostaglandins were reduced by nicotine, which showed an inverse dose dependence, whereas in ferrets no significant effects were observed (Zijlstra et al., 1994).

This study was approved by the Animal Experimental Committee of the Erasmus University of Rotterdam (protocol 118.94.17). Colonic mucosa was obtained from

\footnotetext{
${ }^{*}$ Corresponding author. Department of Pharmacology, Faculty of Medicine and Health Sciences, Erasmus University Rotterdam, P.O. Box 1738, 3000 DR Rotterdam, Netherlands. Tel $(+) 31104087550$, fax $(+) 31104366839$.
}

BALB / c female mice (19-21 g). Nine mice were used as controls, six mice were treated with nicotine. Initially mice received nicotine in drinking water ad libitum: 2 days $25 \mu \mathrm{g} / \mathrm{ml}, 2$ days $50 \mu \mathrm{g} / \mathrm{ml}, 2$ days 100 $\mu \mathrm{g} / \mathrm{ml}$ and 2 days $200 \mu \mathrm{g} / \mathrm{ml}$. Thereafter nicotine was dissolved in saline and given during 14 days subcutaneously by an Alzet osmotic mini-pump with an infusion rate of $200 \mu \mathrm{g} /$ day. Controls received tap water and an osmotic pump filled with saline. Plasma nicotine and cotinine concentrations reflected the dose of nicotine given and were measured by Dr. C. Feyerabend, Nicotine Laboratory, Poisons Unit, New Cross Hospital London, UK. By the third week plasma nicotine and cotinine concentrations were $3.6 \pm 0.61$ and $0.3 \pm 0.05 \mathrm{ng} / \mathrm{ml}$ in controls and $42 \pm 3.0$ and $105 \pm 11$ $\mathrm{ng} / \mathrm{ml}$ in nicotine treated mice respectively. These data were comparable to plasma levels of cotinine $(102 \pm 52 \mathrm{ng} / \mathrm{ml})$ in patients treated with nicotine patches with a release of $15 \mathrm{mg}$ nicotine per day, reflecting 15 cigarettes per day (Pullan et al., 1994).

After the mice were killed by cervical dislocation the colon from hepatic flexure to rectum was removed immediately. The colon was opened in a transverse direction and faeces was removed. The weight of the colon was determined and $2 \mathrm{ml}$ Krebs-Henseleit buffer added, after which the tissue (approx. $200 \mathrm{mg}$ ) was fragmented using an Ultra-Turrax (Polytron, Switzerland) and inflammatory mediators were measured. The amount of protein per mg wet homogenized tissue was 
Table 1

Formation of lipid mediators and cytokines by mouse colonic mucosa after nicotine treatment

\begin{tabular}{lccc}
\hline Mediator & & Controls & Nicotine \\
\hline Protein & $(\mu \mathrm{g} / \mathrm{mg})$ & $11.8 \pm 0.69$ & $12.5 \pm 0.52$ \\
6-Keto-prostaglandin $\mathrm{F}_{1 \alpha}$ & $(\mathrm{pg} / \mathrm{mg})$ & $3620 \pm 428$ & $3500 \pm 341$ \\
Prostaglandin $\mathrm{E}_{2}$ & $(\mathrm{pg} / \mathrm{mg})$ & $1020 \pm 157$ & $1170 \pm 73$ \\
Thromboxane $\mathrm{B}_{2}$ & $(\mathrm{pg} / \mathrm{mg})$ & $316 \pm 53$ & $415 \pm 32$ \\
Leukotriene $\mathrm{B}_{4}$ & $(\mathrm{pg} / \mathrm{mg})$ & $1.5 \pm 0.27$ & $2.9 \pm 0.28$ \\
Leukotriene $\mathrm{C}_{4}$ & $(\mathrm{pg} / \mathrm{mg})$ & $54 \pm 20$ & $1.8 \pm 0.39$ \\
Platelet activating factor & $(\mathrm{pg} / \mathrm{mg})$ & $1.3 \pm 0.60$ & 48.14 \\
Interleukin-1 $\beta$ & $(\mathrm{pg} / \mathrm{mg})$ & $120 \pm 58$ & $13 \pm 13$ a \\
Tumor necrosis factor $\alpha$ & $(\mathrm{pg} / \mathrm{mg})$ & & \\
\hline
\end{tabular}

${ }^{a} P<0.05$ compared with controls.

determined by a micro-scale method (Instruchemie, Netherlands). Eicosanoids were determined by radioimmunoassay, using antibodies from Advanced Magnetics (MA, USA), tritiated compounds from Amersham (UK) and standards from Sigma Co. (USA). Platelet activating factor was determined by radioimmunoassay (PAF-SPA system, Amersham, UK) and cytokines by enzyme-linked immunosorbent assay: tumor necrosis factor $\alpha$ from Genzyme Corp. (USA) and interleukin-1 $\beta$ from Cistron Biotechnology (Eurogenetics, Belgium).

The synthesis of the lipid mediators was unaffected, whereas the production of pro-inflammatory cytokines was completely abolished (Table 1).

This is, as far as we know, the first paper in which the direct effect of nicotine on the synthesis of pro-inflammatory cytokines was investigated and shown to be of a strong inhibitory nature. Recently the effect of exposure to cigarette smoke was investigated in alveolar macrophages in rats (Pessina et al., 1993). As expected tumor necrosis factor $\alpha$ was increased in alveolar macrophages, but surprisingly decreased in peritoneal macrophages $8 \mathrm{~h}$ after the smoking session. In that study peritoneal macrophages were taken as internal control cells and the authors failed to conclude that this unexpected effect could be due to circulating nicotine.

Both tumor necrosis factor $\alpha$ and interleukin- $1 \beta$ are thought to be the most important cytokines involved in the initial events preceding the further development of inflammation in the bowel. Although tumor necrosis factor $\alpha$ and interleukin-1 $\beta$ are mainly produced by macrophages (Pruimboom et al., 1994), other cells also secrete tumor necrosis factor $\alpha$. It was clearly shown that tumor necrosis factor $\alpha$ secreting cells are increased in the mucosa of inflamed intestine (Breese et al., 1994).

Our results offer a possible explanation for the beneficial effects of nicotine in ulcerative colitis.

\section{References}

Breese, E.J., C.A. Michie, S.W. Nicholls, S.H. Murch, C.B. Williams, P. Domizio, J.A. Walker-Smith and T.T. MacDonald, 1994, Tumor necrosis factor $\alpha$-producing cells in the intestinal mucosa of children with inflammatory bowel disease, Gastroenterology 106 , 1455 .

Jones, G.M.M., M. Reith, M.P. Philpot and B.J. Sahakian, 1987, Smoking and dementia of Alzheimer type, J. Neurol. Neurosurg. Psychiatry 50, 1383.

Mills, C.M., S.A. Hill and R. Marks, 1993, Altered inflammatory responses in smokers, Br. Med. J. 307, 911.

Pessina, G.P., L. Paulesu, F. Corradeschi, E. Luzzi, M. Tanzini, C. Aldinucci, A. Di Stefano and V. Bocci, 1993, Chronic cigarette smoking enhances spontaneous release of tumour necrosis factor$\alpha$ from alveolar macrophages of rats, Mediators Inflamm. 2, 423.

Pullan, R.D., J. Rhodes, S. Ganesh, V. Mani, J.S. Morris, G.T. Williams, R.G. Newcombe, M.A.H. Russell, C. Feyerabend, G.A.O. Thomas and U. Säwe, 1994, Transdermal nicotine for active ulcerative colitis, New Engl. J. Med. 330, 811.

Pruimboom, W.M., A.P.M. Van Dijk, C.J.A.M. Tak, I.L. Bonta, J.H.P. Wilson and F.J. Zijlstra, 1994, Interactions between eicosanoids and cytokines: a study using human peritoneal macrophages, Immunol. Lett. 41, 255.

Rhodes, J. and G.O.A. Thomas, 1994, Smoking: good or bad for inflammatory bowel disease?, Gastroenterology 106, 807.

Zijlstra, F.J., E.D. Srivastava, M. Rhodes, A.P.M. Van Dijk, F. Fogg, H.J. Samson, M. Copeman, M.A.H. Russell, C. Feyerabend, G.T. Williams, R.D. Pullan, G.O.A. Thomas, M. Van Blankenstein, J.H.P. Wilson, A. Allen and J. Rhodes, 1994, Effect of nicotine on rectal mucus and mucosal eicosanoids, Gut 35, 247. 